\title{
THE MASS BUDGET OF THE LAMBERT GLACIER DRAINAGE BASIN, ANTARCTICA
}

\author{
By Ian Ailison \\ (Antarctic Division, Department of Science, 568 St Kilda Road, Melbourne, Victoria 3004, \\ Australia)
}

\begin{abstract}
Aвstract. Estimates have been made of the mass budget of the total drainage basin of Lambert Glacier. These show a small but significant positive state of balance for the interior basin (the accumulation area up-stream of the major ice streams), and strongly suggest a positive balance for the Lambert Glacier system (the region of major ice streams, between the Amery Ice Shelf and the interior basin). The total mass flux into the interior basin is estimated as $60 \mathrm{Gt} \mathrm{a}$. Results are presented from a number of ice movement stations established between 1972 and 1974 around the perimeter of the southern Prince Charles Mountains. These results, together with ice thicknesses from radio echo-sounding in the area, give a total mass outflux through the 2 ooo $\mathrm{m}$ contour of $30 \mathrm{Gt} \mathrm{a} \mathrm{a}^{-1}$, implying a budget excess of a further $30 \mathrm{Gt} \mathrm{a}^{-1}$ over the whole interior basin. Results from velocity and ice thickness measurements give a mass discharge through a section near the junction of Lambert Glacier and the Amery Ice Shelf of $11 \mathrm{Gt} \mathrm{a}^{-1}$. Losses within the Iambert Glacier system proper account for a further $7 \mathrm{Gt} \mathrm{a}^{-1}$ and an overall mass excess of $12 \mathrm{Gt} \mathrm{a}^{-1}$ is estimated for the Lambert Glacier system. This present positive state of balance contrasts with geomorphological evidence from the southern Prince Charles Mountains of a large drop in ice level in recent geological time, and the ice surface in the area may now be building up after a major recession.
\end{abstract}

RÉsumé. Le bilan du bassin venant du Lambert Glacier, Antarctique. On a procédé à des estimations du bila $n$ de l'ensemble du bassin versant du Lambert Glacier. Elles mont rent un bilan faiblement mais significativement positif pour l'intéricur du bassin (la zone d'accumulation à l'amont du couraat principal de glace) et appuicnt fortement l'hypothèse d'un bilan positif pour l'ensemble du système du Lambert Glacier (la région du courant principal de glace, entre l'Amery Ice Shelf et le bassin intérieur). Le flux total de masse entrant dans le bassin intérieur est estimé à $60 \mathrm{Gt}$ par an. Les résultats sont présentés pour un nombre de stations de mesure de mouvement de la glace établies entre 1972 et 1974 autour du périmètre du Sud des Prince Charles Mountains. Ces résultats, ainsi que les épaisseurs de glace déduites de sondage par écho radio, donnent un flux total en masse sortant à travers la ligne de niveau $2000 \mathrm{~m}$ de $30 \mathrm{G}$ t par an, voit un budget en excédent de plus de $30 \mathrm{Gt}$ par an sur l'ensemble du bassin intérieur. L.es résultats des mesures de vitesse et d'épaisseur de glace donnent un débit de masse à travers une section voisine de la confluence du Lambert Glacier avec l'Amery Ice Shelf de i $\mathrm{Gt}$ par an. Les pertes dans l'appareil glaciaire de Lambert lui-méme interviennent pour plus de $7 \mathrm{Gt}$ par an et on estime que le bilan est excédentaire de 12 (it par an. Cict état présent positif du bilan contraste avec les signes géomorphologiques provenant du Sud des Prince Charles Mountains d'une forte baisse du niveau de la glace à une époque géologique récente, et la surface de la glace dans ce secteur peut être maintenant en progression après une récession majcurc.

Z.usammenfassung. Der Massenhaushalt des Lambert-Glaciers-Ausflussbeckens, Antarktika. Für den Massenhaushalt des gesamten Einzugsgebietes des Lambert-Glaciers wurden Abschätzungen angestellt. Diese zeigen eine geringfügig, aber doch signifikant positive Bilanz für das innere Becken (das Akkumulationsgebiet oberhalb der grösseren Eisströme) an und lassen deutlich eine positive Bilanz für das Systcm des LambertGlaciers (das Gebiet der grossen. Eisströme zwischen dem Amery lce Shelf und dem inneren Becken) vermuten. Der gesamte Zustrom in das innere Becken beträgt schätzungsweise 6o Gt pro Jahr. Es werden Ergebnisse einiger Stationen vorgelegt, die zur Bestimmung der Eisbewegung zwischen 1972 und r 974 rund um den Fuss der südlichen Prince Charles Mountains angelegt wurden. Zusammen mit Eisdicken aus RadarEchomessungen in diesem Gebiet ergeben sie einen Gesamtdurchfluss von $30 \mathrm{Gt}$ pro.Jahr durch das Vertikalprofil längs der $2000 \mathrm{~m}$-Höhenlinie, was auf einen Überschuss von weiteren 30 Git pro Jahr für das ganze innere Becken schliessen lässt. Geschwindigkeits- und Dickenmessungen ergeben cinen Massenausstoss von I I Gt pro Jahr durch ein Profil nahe der Mündung des Lambert-Glaciers in das Amery Ice Shelf. Weitere $7 \mathrm{Gt}$ pro Jahr gehen im eigentlichen Lambert-Gletschersystem verloren, so dass sich cin Gesamtüberschuss von $12 \mathrm{Gt}$ pro Jahr für das System abschätzen lässt. Diese derzeit positive Bilanz steht im Gegensatz zu der geomorphologischen Beobachtung einer starken Senkung der Eisoberfläche in geologisch junger 7.eit aus den südlichen Prince Charles Mountains; die Eisoberfläche in diesem Gebiet dürfte daher jetzt nach cinem
beträchtlichen Abbau wieder ansteigen.

\section{Introduction}

Lambert Glacier (long. $68^{\circ}$ E., lat. $71-75^{\circ} \mathrm{S}$.) is the largest ice stream in the world with a width of over $40 \mathrm{~km}$ and a length, from the grounding line of the Amery Ice Shelf to the southernmost point where surface flow lines are visible on Landsat imagery, of $400 \mathrm{~km}$. At its deepest the ice is $2500 \mathrm{~m}$ thick (Morgan and Budd, 1975). 
The glacier lies in a graben-like rift valley running along long. 68 E. and extending from the coast to south of lat. $75 \mathrm{~S}$. (Wellman and Tingey, 1976; Fedorov and others, in press). The graben is bounded on the western side by the Prince (iharles Mountains and on the eastern side in the south by the Mawson escarpment. The amplitude of bedrock relief within the glacier valley reaches over $3500 \mathrm{~m}$ and at its deepest the bedrock is more than $2000 \mathrm{~m}$ below sea-level. Tingey (in press) describes the geology of the region.

Lambert Glacier feeds into the $300 \mathrm{~km}$ long Amery Ice Shelf and with its major tributaries, Mellor and Fisher Glaciers, drains a large sector of the interior of East Antarctica. The ice drainage through this system causes a major $600 \mathrm{~km}$ by $300 \mathrm{~km}$ trough in the East Antarctic ice sheet (Trail, 1964). Giovinetto (1964) identifies the Amery Lambert drainage basin as the fourth largest in Antarctica. Because of its importance to the overall Antarctic mass balance, a number of previous attempts have been made to estimate the total mass budget or mass input of the Amery-Lambert system (e.g. Mellor, 1959[a]; Mellor, 1964; Giovinetto, 1964,1970 ; Budd and others, 1967). The mass budgets all suggest that the basin has a positive balance, although most estimates have been based on very limited data.

The Amery Ice Shelf has been extensively studied by Australian National Antarctic Research Expeditions (A.N.A.R.E.) in 1962, 1963, and r964 (Budd, rg66; Budd and others, 1967 ) and more recently in 1968 and 1970.

For the present study, the total Lambert Glacier drainage basin is divided into two sub-areas: the Lambert Glacier system and the interior basin (Fig. I). The Lambert Glacier system is defined as the area between the southern end of the Amery Ice Shelf and a perimeter through a number of ice movement stations around the Prince Charles Mountains (Fig. 2). This area includes most of the major ice streams. The interior basin is defined as that inland accumulation area which drains into the Lambert Glacier system.

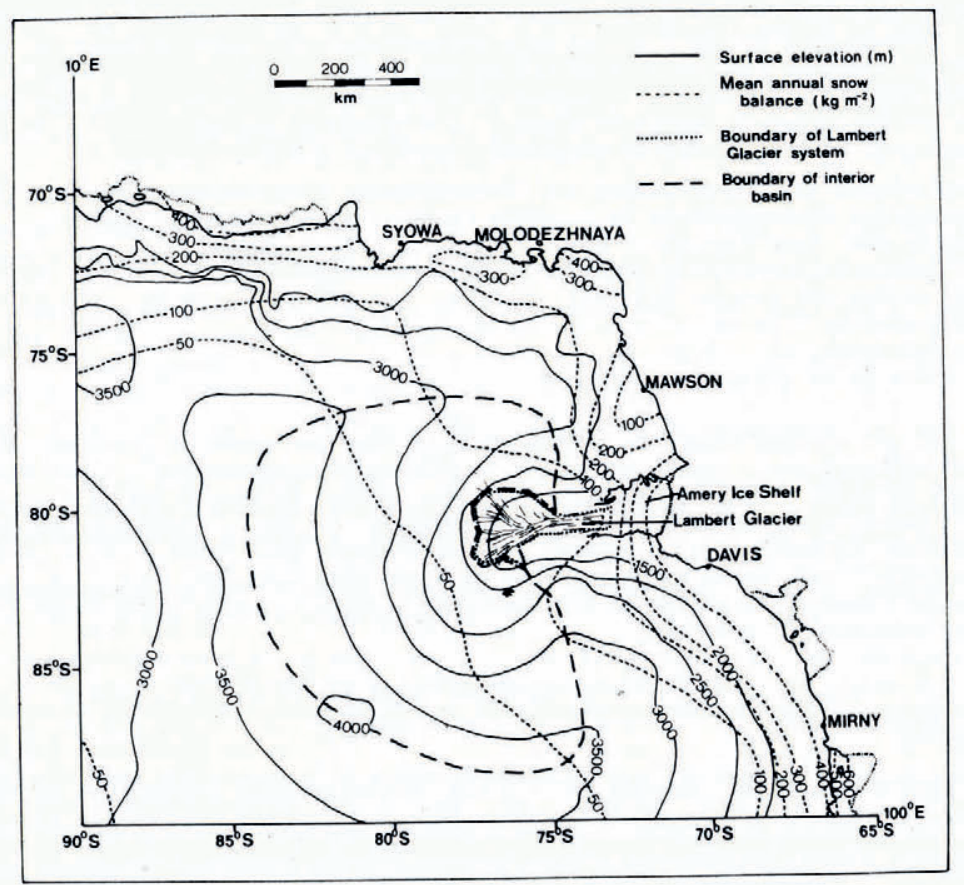

Fig. I. The Lambert Glacier drainage basin: surface elevation contours and net accumulation isopleths. 


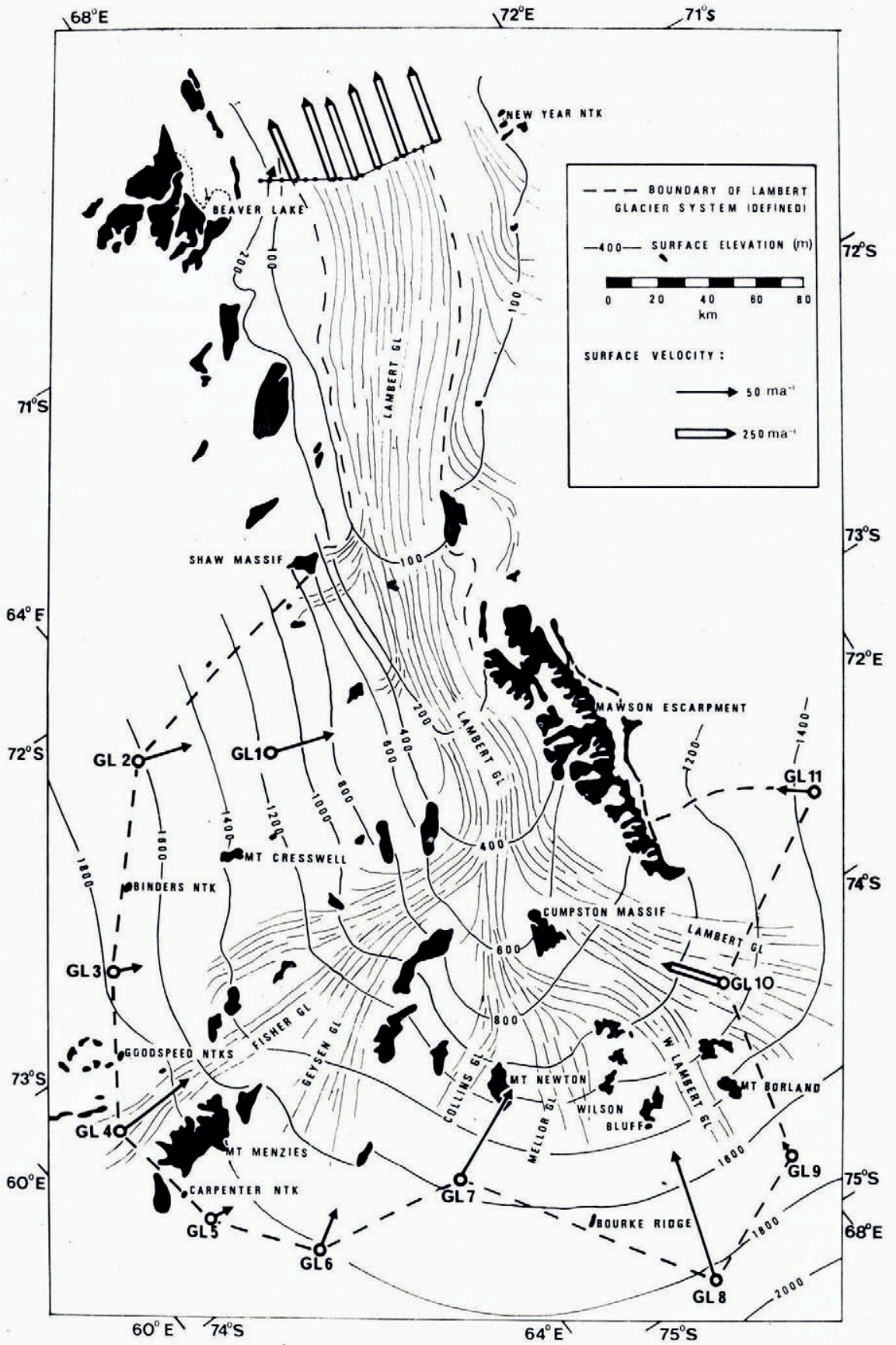

Fig. 2. The Lambert Glacier system: measured ice velocities around the perimeter and across the Amery Ice Shelf. 
Unpublished data from the 1968 and 1970 ice-shelf surveys, together with the results of measurements in the Lambert Glacier basin, are used to estimate the total mass flux

(i) resulting from net accumulation in the interior basin,

(ii) draining into the Lambert Glacier system through a perimeter around the Prince C:harles Mountains, and

(iii) flowing into the southern end of the Amery Ice Shelf.

\section{Glaciological stidies in the Lambert Glacier basin}

1) uring the austral summer of $1971 / 72$, eleven ice-movement stations were established during an A.N.A.R.E. air-supported, multi-disciplinary field programme in the southern Prince ('harles Mountains. The stations, established beyond the mountains in a perimeter around the system of Lambert Glacier and its tributaries, were resurveyed during the summer of $1973 / 74$. Aerial radio echo-sounding of ice thickness was carried out at the same time and the results of this programme have been reported by Morgan and Budd (1975).

The position of the stations was selected to give a representative sample of the ice flow into the Lambert Glacier system, with one station sited on the up-stream region of each of three major ice streams (Lambert, Fisher, and Western Lambert Glaciers) and with other stations in areas of fairly uniform sheet flow. Most of the stations were at elevations between $1500 \mathrm{~m}$ and $2000 \mathrm{~m}$ and more than $30 \mathrm{~km}$ from the nearest mountain or nunatak. The positions of the stations are given in Table 1 .

Table: I. Position of the Lambert Glacilo basin ice-movement stations

\begin{tabular}{|c|c|c|c|c|}
\hline Station & Description & Latitude south & Longitude east & $\begin{array}{l}\text { Elevation } \\
\mathrm{m}\end{array}$ \\
\hline (GI. 1 & $\begin{array}{l}\text { Firn NE of Mount Cresswell. Several straight narrow } \\
\text { crevasses run } 130-210 \text { T. Sastrugi oriented SII NE }\end{array}$ & $72.30^{\prime} 58.3^{\prime \prime}$ & $65 \quad 19^{\prime} 16.4^{\prime \prime}$ & $114^{8}$ \\
\hline (;L 2 & $\begin{array}{l}\text { Slight depression N.NII of Mount Ciresswell. Moderately } \\
\text { hard firn }\end{array}$ & $7.215^{\prime} 31.00^{\prime \prime}$ & $635^{8^{\prime}} 00.0^{\prime \prime}$ & 1607 \\
\hline (;L $\quad 3$ & $\begin{array}{l}\text { Fairly sofi snow with wind-hardened slabs. West of Mount } \\
\text { Cresswell }\end{array}$ & $7 \cdot 2+8^{\prime} \cdot 25 \cdot 9^{\prime \prime}$ & $6209^{\prime} 03.5^{\prime \prime}$ & 1 808 \\
\hline GL + & $\begin{array}{l}\text { On Fisher Cilacier NII of Mount Menzies. Many firn- } \\
\text { bridged crevasses }\end{array}$ & $7315^{\prime} 01.8^{\prime \prime}$ & $6059^{\prime} 53.9^{\prime \prime}$ & $20 \cdot 20$ \\
\hline GL 5 & Hard firn SII of Mount Menzies. Sastrugi run N-S & $73 t^{\prime}, 5+1^{\prime \prime}$ & $6111^{\prime} 2$ & 2000 \\
\hline GL 6 & Firn with sastrugi SE of Mount Menzies & $740_{3} 0^{\prime} 03.4 "$ & 61 & 1 889 \\
\hline GL 7 & $\begin{array}{l}\text { Among many highly erevassed domes Sil of Mount } \\
\text { Newton. Very hard firm }\end{array}$ & $7+13+7 \cdot 4$ & $643^{\prime}$ & $155^{6}$ \\
\hline $\begin{array}{ll}\text { GL } & 8 \\
\text { GL } & 9\end{array}$ & Firn with sastrugi SSW of Wilson Blufl & $7+5^{8}+4 \cdot 0^{\prime \prime}$ & $6606^{\prime \prime} \cdot 29.0^{\prime \prime}$ & 1763 \\
\hline $\begin{array}{lr}\text { GL } & 9 \\
\text { (iL. } & \text { I }\end{array}$ & th sastrugi SE of Wilson Bluff & $74+5,10.1^{\prime \prime}$ & $6757^{\prime}, 30 \cdot 3^{\prime \prime}$ & 1710 \\
\hline GL Io & $\begin{array}{l}\text { On fine-grained snow on Lambert (ilacier. Inmediate } \\
\text { area crevasse free and subject to strong lateral compres- } \\
\text { sion }\end{array}$ & $7+04^{\prime} 13.0^{\prime \prime}$ & $6823^{\prime} \cdot 20.4^{\prime \prime}$ & 1 I 09 \\
\hline GL I I & $\begin{array}{l}\text { On fine-grained snow surface east of the south tip of } \\
\text { Mawson escarpment. Crevassed ice ridge } 8,6 \mathrm{~km} \text { cast }\end{array}$ & $7343^{\prime} 44 \cdot 6^{\prime \prime}$ & $70 \quad 37^{\prime} 00.0^{\prime \prime}$ & $14^{62}$ \\
\hline
\end{tabular}

The position of the stations was determined by tellurometer measurement and horizontal angles read from triangulation stations on mountain summits. Elevations were found from reciprocal vertical angles measured to the mountains. All survey measurements were to second-order accuracy. Other measurements made at the stations included net balance, strain-rates (on small strain grids of arm length of only $100 \mathrm{~m}$ ), $10 \mathrm{~m}$ firn temperatures, gravity, and surface slope. $10 \mathrm{~m}$ firn cores were also collected for oxygen-isotope measurements.

Relevant data from the stations are given in Table II and the velocity vectors are also plotted in Figure 2. Surface ice velocities are accurate to $\pm 0.4 \mathrm{~m} \mathrm{a}^{-1}$. The highest measured velocity, $230 \mathrm{~m} \mathrm{a}^{-1}$, occurs on Lambert Glacier and very high strain-rates were also measured 
Tabi.f. II. Data from ICE movement stations in the Lambert Glacier basin

\begin{tabular}{|c|c|c|c|c|c|c|c|c|}
\hline \multirow[b]{4}{*}{ Station } & & & \multicolumn{2}{|c|}{ Tangent of surface slope } & \multirow[b]{4}{*}{$\begin{array}{c}\text { Ice } \\
\text { thickness } \\
\mathrm{m}\end{array}$} & \multirow{4}{*}{$\begin{array}{c}10 \mathrm{~m} \\
\text { firn } \\
\text { temperature } \\
\mathrm{C}\end{array}$} & \multirow{2}{*}{\multicolumn{2}{|c|}{$\begin{array}{l}\text { Net balance } \\
\mathrm{m} \text { water } \mathrm{a}^{-1}\end{array}$}} \\
\hline & \multirow{2}{*}{\multicolumn{2}{|c|}{ Surface velocity }} & Mean & Mean & & & & \\
\hline & & & slope & slope & & & Mean of & \\
\hline & $\begin{array}{c}\text { Speed } \\
\mathrm{ma} \mathrm{a}^{\prime}\end{array}$ & $\begin{array}{c}\text { Direction } \\
\mathrm{T}\end{array}$ & $\begin{array}{l}0 t e r \\
5 \mathrm{~km} \\
510^{3}\end{array}$ & $\begin{array}{c}\text { over } \\
50 \mathrm{~km}^{2} \\
10^{3}\end{array}$ & & & $\begin{array}{l}\text { Jive stake } \\
\text { network }\end{array}$ & $\begin{array}{l}\text { Standard } \\
\text { deviation }\end{array}$ \\
\hline GL I & $4^{6.5}$ & 107.5 & - & 12.0 & 1510 & $-28 . \mathrm{I}$ & 0.01 & 0.01 \\
\hline GL $\quad 2$ & $4^{1.8}$ & 110.9 & - & 6.4 & $175^{\circ}$ & -30.3 & +0.04 & 0.01 \\
\hline GI. 3 & 19.5 & 117.9 & 9.1 & 8.8 & 480 & - & -0.01 & 0.01 \\
\hline GI 4 & 68.3 & 92.3 & 23.9 & 6.0 & $205^{\circ}$ & -36.5 & +0.01 & 0.04 \\
\hline GL 5 & I6.0 & 102.8 & 1.5 & 7.8 & 1200 & -35.8 & $+0.3^{2}$ & 0.01 \\
\hline GL $\quad 6$ & 33.5 & 62.6 & $9 \cdot 4$ & 5.6 & 1710 & - & +0.11 & 0.01 \\
\hline GI. 7 & 78.5 & $64 \cdot 9$ & 6.2 & 7.0 & 1800 & 33.2 & 0.02 & 0.02 \\
\hline GL 8 & 106.0 & 17.6 & 8.7 & 6.8 & $13.5^{\circ}$ & -34.7 & 0.07 & 0.03 \\
\hline GL 9 & 7.0 & 11.8 & 4.7 & 6.4 & 430 & DT & +0.08 & 0.02 \\
\hline GL Io & 230.5 & 321.8 & 9.6 & 7.2 & $195^{\circ}$ & - & +0.08 & 0.03 \\
\hline GL I I & 24.5 & 306.8 & - & 5.6 & 800 & 27.8 & +0.06 & 0.01 \\
\hline
\end{tabular}

at this site. Principal strain-rates were $+7.5 \times 10^{-3} \mathrm{a}^{-1}$ in the direction of flow and a strong compression of $-20.6 \times \mathrm{rO}^{-3} \mathrm{a}^{-1}$ perpendicular to the flow due to convergence of the ice stream between the Mawson escarpment and the mountains to the west. Other high velocities were also measured up-stream of Western Lambert, Collins, and Fisher Glaciers while stations on more uniform ice moved at about $20-40 \mathrm{~m} \mathrm{a}^{-1}$.

Two different estimates of surface slope are given in Table II. The mean surface slope over $50 \mathrm{~km}$ has been obtained from the surface elevation data of Morgan and Budd (1975) while slopes over $5 \mathrm{~km}$ were obtained by measuring vertical angles to a helicopter positioned $2.5 \mathrm{~km}$ up-stream and down-stream of the stations. The ice thicknesses are taken from the original data used by Morgan and Budd ( 1975 ).

Net balance measurements were made at the central steel marker pole and the four canes of the strain grids at each station. With the exceptions of station GL. 5 and to a lesser extent GL 6, which are probably affected by their closeness to the massive Mount Menzies, the net balances are all less than $0.1 \mathrm{~m}$ water $\mathrm{a}^{-1}\left(100 \mathrm{~kg} \mathrm{~m}^{-2} \mathrm{a}^{1}\right.$ ) and some stations show a net ablation. The net balance is poorly correlated with temperature and elevation.

The $10 \mathrm{~m}$ firn temperatures were measured in a bore hole with a thermistor bridge. As expected, the temperatures are well correlated with elevation $(r=0.90)$, with temperature decreasing at a rate of $\mathrm{I} \mathrm{deg} / \mathrm{l} 00 \mathrm{~m}$ of elevation. Air temperature during the period of field work (January) varied between $-9^{\circ} \mathrm{C}$ and $-24^{\circ} \mathrm{C}$.

\section{THE INTERIOR BASIN}

The area of the interior basin has been determined from ice flow lines constructed perpendicular to the surface elevation contours. The surface elevations (Fig. 1) are based on the American Geographical Society I : 5000 ooo map of Antarctica published in 1970, although adjustments have been made for the more recent data available around the southern Prince Charles Mountains (Morgan and Budd, 1975, and the present study) and for the sector long. $4^{\circ}$ E. $5^{\circ}$ E. covered by J.A.R.E. traverses (Fujiwara and others, 1971; Shimizu, 1977). There is a complete lack of elevation data in the centre of the basin (between latitudes $75{ }^{\circ} \mathrm{S}$. and $80 \mathrm{~S}$.) although the southern ice divide is somewhat better defined from data from a number of traverses.

The area of the accumulation basin, up-stream of the ice movement stations, is $1.09 \times 10^{6}$ $\mathrm{km}^{2}$. No true error estimate for this value can be given but, since the boundaries of the basin are mostly near traverse routes, the error is unlikely to exceed $20 \%$. 
Bull (1971) and Kotlyakov and others (1974) both compiled available data to produce maps of the distribution of mean annual snow balance for the whole of Antarctica. While the two distributions, in the area of interest to the present study, are very similar in coastal regions, they show significant differences in the interior around long. $90^{\circ} \mathrm{E}$. The distribution given by Kotlyakov and others (1 974), which includes data from the Soviet traverses inland of Mirny, is regarded as more reliable and has been used as the basis of the isopleths of mean annual snow balance shown in Figure I. However, the lack of data from the interior of the Lambert Glacier accumulation basin allows several possible interpretations of the distribution of accumulation in that area. The low value of net accumulation $\left(<100 \mathrm{~kg} \mathrm{~m}^{-2} \mathrm{a}^{-1}\right)$ at most of the basin ice-movement stations suggests that the $100 \mathrm{~kg} \mathrm{~m}^{-2} \mathrm{a}^{-1}$ isopleths may actually pass to the north of Lambert Glacier and the isopleths of Figure I have been accordingly modified from those of Kotlyakov and others (1974).

Using this distribution of net accumulation, the total mass influx into the interior basin is $60 \mathrm{Gt} \mathrm{a}^{-1}$ which is equivalent to an average net accumulation over the basin of $55 \mathrm{~kg} \mathrm{~m}^{-2} \mathrm{a}^{-1}$. Again no reliable error estimate of this value can be made, although it is most likely to be near the minimum probable value. The net accumulation distributions of Kotlyakov and others (1974) lead to a total mass influx of $78 \mathrm{Gt} \mathrm{a}^{-1}$ (a mean net accumulation of $72 \mathrm{~kg} \mathrm{~m}^{-2} \mathrm{a}^{-1}$ ). Allowing for errors in the estimate of the area it would seem highly unlikely that the total mass influx lies outside the range of $4^{2}$ to $\mathrm{I}_{\mathrm{O}} \mathrm{Gt} \mathrm{a}^{-1}$.

On the basis of earlier data, Mellor ( 1964 ) and Giovinetto (1964) estimate the mass flux required to flow through Lambert Glacier at lat. $73^{\circ} \mathrm{S}$. for equilibrium. Mellor estimates a total flux of $8 \mathrm{I} \mathrm{Gt} \mathrm{a}^{-1}$ (an average accumulation of $90 \mathrm{~kg} \mathrm{~m}^{-2} \mathrm{a}^{-1}$ over an area of $0.90 \times 10^{6}$ $\left.\mathrm{km}^{2}\right)$ and Giovinetto estimates a flux of $46 \pm 26 \mathrm{Gt} \mathrm{a}^{-1} \quad\left(39 \pm 10 \mathrm{~kg} \mathrm{~m}^{-2} \mathrm{a}^{-1}\right.$ over $\left(1.19 \pm 0.3^{6}\right) \times 10^{6} \mathrm{~km}^{2}$ ). If ablation losses on Lambert Glacier are neglected, the present study gives an influx of $46 \mathrm{Gt} \mathrm{a}^{-1}\left(4^{8} \mathrm{~kg} \mathrm{~m}^{-2} \mathrm{a}^{-1}\right.$ average net accumulation over $0.95 \times \mathrm{IO}^{6}$ $\mathrm{km}^{2}$ ) for this portion of the drainage basin.

\section{Mass flux into the Lambert Glacier system}

The mass flux into the Lambert Glacier system has been estimated from data from the ice movement stations.

Figure 3 shows the distribution of ice thickness and surface ice velocity around a perimeter through the stations. The ice thickness has been determined from the published echosounding results of Morgan and Budd (1975) and from the original data used in their study. Between the ice movement stations, the surface velocity has been interpolated with reference to the ice thickness. Visible flow lines on the Landsat I imagery of the area were used to identify any fast-moving ice streams crossing the perimeter.

The basal shear stress

$$
\tau_{\mathrm{b}}=\rho g \alpha Z,
$$

where $Z$ is the ice thickness, $\alpha$ is surface slope, $\rho$ is ice density, and $g$ is the acceleration due to gravity, is close to or less than I bar at all the ice movement stations with the exception of GL Io, and the measured ice velocities can be explained by internal ice deformation with zero or negligible basal sliding. Hence, for the cold ice around the perimeter, the relationship between surface velocity $V_{\mathrm{s}}$ and the mean velocity of the column $\bar{V}$, has been taken as

$$
\bar{V}=\frac{\mathrm{I}}{z} \int_{\mathrm{o}}^{z} V(z) \mathrm{d} z=0.8 V_{\mathrm{s}}
$$

Because the perimeter considered is not orthogonal to the ice flow, the flux rate of ice $\Phi$ per unit width is given by

$$
\Phi=0.8 V_{\mathrm{s}} Z \sin \phi
$$




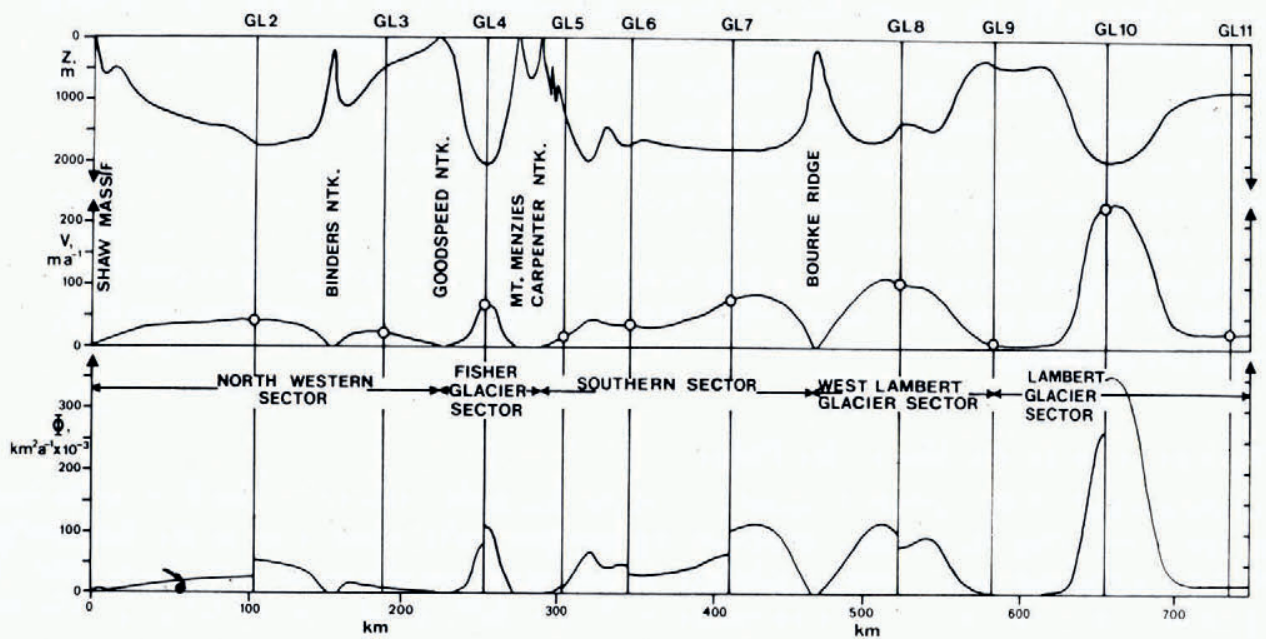

Fig. 3. Cross-section of ice thickness, surface velocity, and flux rate per unit width around the perimeter of the Lambert Glacier system.

where $\phi$ is the angle between the perimeter and the flow direction. At points between ice movement stations, $\phi$ has been determined from flow lines on the Landsat imagery, where visible, or by assuming that the ice flow direction is orthogonal to the surface elevation contours of Morgan and Budd (1975).

The calculated values of $\Phi$ are shown in Figure 3. Discontinuities occur where the defined perimeter changes direction. The perimeter can be subdivided into five major regions of mass flux: a sector of fairly uniform mass flux in the north-west between Shaw Massif and Goodspeed Nunataks; Fisher Glacier; the section to the south which includes drainage into Geysen, Collins, and Mellor Glaciers; Western Lambert Glacier (the branch of Lambert Glacier between Wilson Bluff and Mount Borland); and the major branch of Lambert Glacier. The maximum flux per unit width of over $0.35 \mathrm{~km}^{2} \mathrm{a}^{-1}$ of ice occurs in the centre of the main branch of Lambert Glacier.

The total mass flux for each sector, assuming an ice density of $0.87 \mathrm{t} \mathrm{m}^{-3}$, is given in Table III. The mass flux into the Lambert Glacier system through the whole perimeter amounts to $30 \mathrm{Gt} \mathrm{a}{ }^{-1}$.

An attempt was made to obtain some idea of the error involved in the interpolation between the measurement points, by estimating the flux from an interpolation based on only half the ice radar data. The resultant distribution of mass flux around the perimeter was

Table III. Mass flux into the Lambert Glacier system

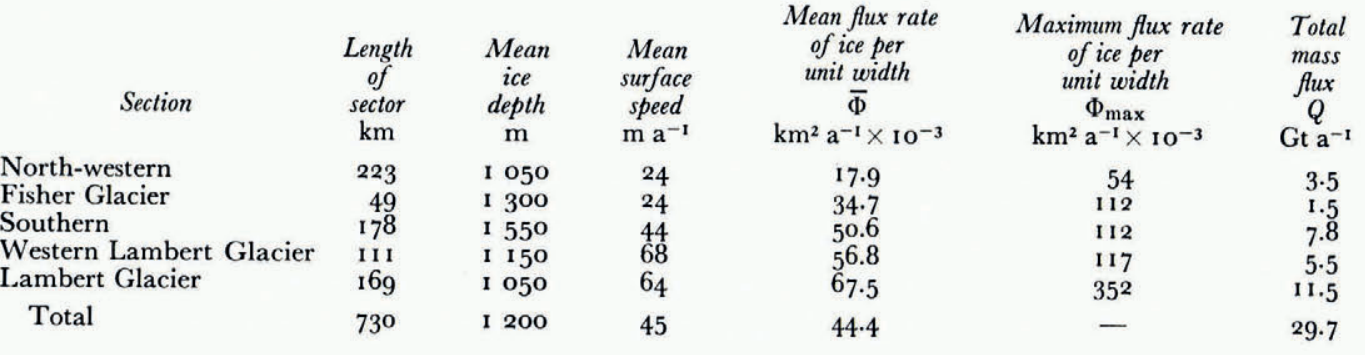


similar to that in Figure 3 and the total mass flux estimate was less than $15^{\circ} \circ$ different. In addition, for the sector between Binders Nunatak and Shaw Massif, the mass flux was estimated across a redefined perimeter, parallel to the surface contours. The estimated flux into the basin across this perimeter was about $20^{\circ}$, greater than that from Figure 3 .

Interpolation errors will be most important in the fast-moving ice streams. For example a 1o $\mathrm{km}$ error in defining the width of the high-velocity core of Lambert Glacier would give about a $10^{\circ}{ }_{0}$ error in the total flux. However the width of the fast-moving ice streams can. be fairly accurately determined from visible flow lines on the Landsat photographs. ()verall it would seem reasonable to assign error limits of $\pm 30^{\circ}$, to the total estimated mass flux through the perimeter.

\section{Mass fill $x$ into the Amery Ice Shelf}

During 1968 a tellurometer traverse was made across the Amery Ice Shelf between Beaver Lake and New Year Nunataks. Stakes along this line were resurveyed at the beginning of 1970 and continuous radio echo-sounding of ice thickness was obtained at the same time. The resultant ice velocities and ice thickness across the ice shelf are shown in Figure 4. Velocities are accurate to $t_{1} \mathrm{~m} \mathrm{a}^{-1}$ and ice thickness to $\pm 20 \mathrm{~m}$.

The sector of the ice shelf fed from the Lambert Glacier system has been determined from flow lines visible on the Landsat imagery. Flow lines are clearly discernible and the width of the ice shelf originating from Lambert Glacier can be determined to within a few kilometres. The ice originating from Lambert Glacier corresponds well with the high-velocity core of the ice shelf. This ice has a fairly constant thickness and velocity across the ice shelf; the mean thickness is $743 \pm 20 \mathrm{~m}$ and the mean velocity $340 \pm 5 \mathrm{~m} \mathrm{a}^{-1}$. Isostasy considerations show that this section of the ice shelf is free-floating with a mean density of $0.88 \mathrm{t} \mathrm{m}^{-3}$ and hence the mean column velocity is equal to the surface velocity.

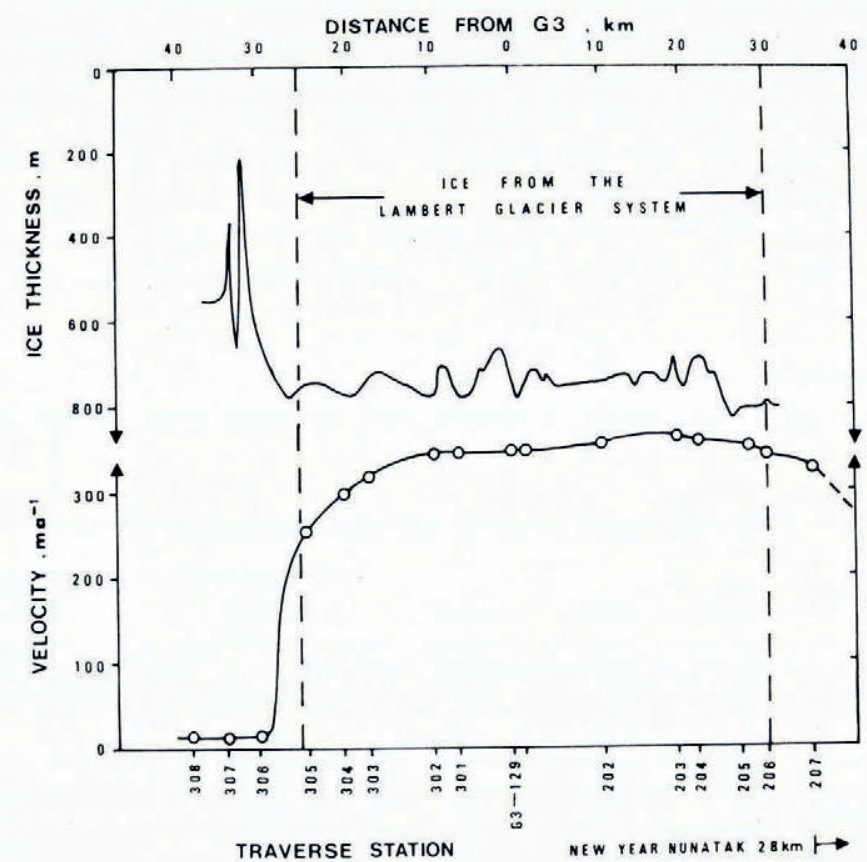

Fig. f. Cross-section of ice thichiness and ielocity near the grounding line of the Amery Ice Shelf. 
The arms of the traverse route were not exactly orthogonal to the ice flow and the width of the cross-section of the Amery Ice Shelf at right-angles to the flux is $50 \mathrm{~km}-10^{\circ}{ }_{12}$. The total mass flux through this section of the ice shelf is 11.1 Gt a $1+15^{\circ},$.

\section{Mass Loss within the Lambert Gi.Acier SYSTLM}

Much of the Lambert Glacier system is an area of net ablation and melt streams and lakes form on the glacier surface during summer. The $10 \mathrm{~m}$ firn temperature at $\mathrm{G}_{3}$ is $-23^{\circ} \mathrm{C}$ : (Budd, 1966) and that at GL I is - 28 (: indicating an annual mean air temperature in the glacier basin of around $-25 \mathrm{C}$. Mean summer temperatures are about $-10^{\circ} \mathrm{C}$ to $-15^{\circ} \mathrm{C}$. At these temperatures ablation due to evaporation only is small, 0.05 to $0.10 \mathrm{~m}$ water $\mathrm{a}^{-1}$ (Budd, 1967), and even allowing for a strong radiative effect from the Mawson escarpment and surrounding mountains, the ablation rate is unlikely to exceed $0.15 \mathrm{~m}$ water $\mathrm{a}^{-1}$.

The area subject to net ablation was found from the well-delineated blue-ice areas on Landsat photographs to be $33.2 \times \mathrm{rO}^{3} \mathrm{~km}^{2}$. The rest of the Lambert Glacier system is assumed to have a zero net balance. The total mass loss from evaporation in the basin is estimated at $5.0 \mathrm{Gt} \mathrm{a}^{-1}$ and the limits on this estimate are about $1.7 \mathrm{Gta}^{-1}$ a mean ablation rate of

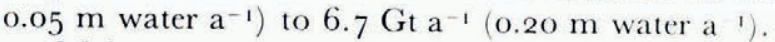

Melt water is extensive on the glacier surface during summer (Mellor and McKinnon, $1960)$, but it is thought that this water refree\%es in winter. in the firn or in crevasses, and represents a mass redistribution rather than a mass loss Budd and others, 1967). Weertman (1973) suggests that water-filled crevasses can reach the bottom of a temperate glacier but no allowance for melt-water loss has been made in this study:

Budd and others ([ 1970$]$ ) calculate that a large part of the Lambert Glacier basin is at the pressure-melting point and mass loss by basal melt must be considered.

The distribution of basal shear stress $\tau_{1}$, within the glacier system was calculated from ice thicknesses and surface slopes derived from the work of Morgan and Budd 1975). Downstream from the ice movement stations the shear stress remains fairly constant at a value of around I bar, until reaching the upper parts of the major ice streams where it rapidly increases to 1.5 to 2 bar. The point of rapid increase coincides with a change in surface slope between the mountains from convex up to concave up and it is assumed that basal slipping sets in in this region. The area of basal melt is assumed to cover the regions down-stream from where the shear stress reaches 1.5 bar, and includes all the major ice streams.

Within the upper parts of the ice streams the shear stress remains fairly constant but in the main Lambert Glacier it decreases gradually from 1.5 bar north of (iumpston Massif, to very low values of about o. I bar near the Amery Ice Shelf. It is thought that the lower Lambert Glacier, with a very low surface slope but high velocity, is moving almost completely by basal sliding. North of Mount Stinear, basal stresses reach between 1.5 and 4 bar in the region of high surface slope on the western boundary of the lower Lambert Glacier. Basal melting is also assumed to occur in this region.

Where the basal ice is at the pressure-melting point, the melt rate $.1 /$ is given by

$$
\text { .I } \tau_{1,} \Gamma / \text {. }
$$

where $I$, is the latent heat of fusion of ice $0.334 \mathrm{MJ} \mathrm{kg} 1)$. The estimated melt rate for different regions of the lambert Glacier system is given in lable IV. The total estimated melt of $2 \mathrm{Gt} \mathrm{a}^{-1}$ should be considered as very approximate, but represents only a small term in the total budget. Error limits are probably of the order of $+100^{\circ}{ }_{0}$.

Fedorov and others in press) present evidence for the existence of a second large rifi valley to the east of the Mawson escarpment, although it now has no reflection in the sub-ice topography. The existence of a valley on the east of the escarpment could result in an outflow of ice in the region of GL 1 I from the defined Lambert Glacier system. Flow lines on the 


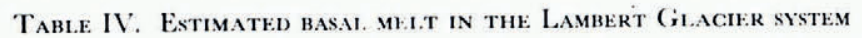

\begin{tabular}{|c|c|c|c|c|c|}
\hline & $\underset{\mathrm{km}^{2} \vee{ }_{10}}{\text { Area }}$ & $\begin{array}{l}\text { Average } \\
\text { velocity } \\
\qquad \bar{\Gamma} \\
\mathrm{m} \mathrm{a}^{-1}\end{array}$ & $\begin{array}{c}\text { Average basal } \\
\text { shear stress } \\
\tau_{\mathrm{b}} \\
\text { bar }\end{array}$ & $\begin{array}{l}\text { Melt } \\
\text { rate } \\
M \\
\mathrm{~kg} \mathrm{~m}^{-2} \mathrm{a}^{-1}\end{array}$ & $\begin{array}{c}\text { Total } \\
\text { melt } \\
\text { Gt } \mathrm{a}^{-1}\end{array}$ \\
\hline $\begin{array}{l}\text { Fast ice streams (upper Lambert, } \\
\text { Western Lambert, Mellor, Collins, } \\
\text { Geysen, and Fisher Glaciers) }\end{array}$ & 11.5 & 200 & 2 & 120 & 1.4 \\
\hline Lower Lambert Glacier & 11.9 & $35^{\circ}$ & 0.4 & $4^{2}$ & 0.5 \\
\hline West bank of lower Lambert Glacier & $4 \cdot 4$ & 50 & 3 & 45 & 0.2 \\
\hline
\end{tabular}

Landsat photographs show strong flow to the east of the northern part of the escarpment but no evidence that the flow line through GL I I turns northward to the east of the escarpment. The velocity vector at GL i i shows no strong preferred orientation for the eventual northward flow being to the east of the escarpment or in the main Lambert stream. The flow has been considered to reach the main Lambert Glacier eventually, although an estimated outflow between GL 1 i and the Mawson escarpment of $2 \mathrm{Gt} \mathrm{a}^{-1}\left(75^{0} \mathrm{~m}\right.$ thickness moving at $5^{\left.0 \mathrm{~m} \mathrm{a}^{-1}\right)}$ is considered in the error estimates.

The estimated total ice loss from within the Lambert Glacier system is $7 \mathrm{Gt} \mathrm{a}^{-1}$, with probable limits between about $2 \mathrm{Gt} \mathrm{a}^{-1}$ and ${ }_{1} 3 \mathrm{Gt} \mathrm{a}^{-1}$.

\section{Discussion}

The mass budgets for the interior basin and the Lambert Glacier system, as well as for the total drainage basin, are given in Table V. In all cases there is a positive budget despite the fact that influx terms have been estimated conservatively while loss terms have been maximized throughout this study. The limits given in Table $\mathrm{V}$ are for the worst possible combination of magnitude and sign of the estimated errors discussed above.

For the interior basin the mass surplus of $30 \mathrm{Gt} \mathrm{a}^{-1}$ is equivalent to a surface rise of 0.03 $\mathrm{m}$ water $\mathrm{a}^{-1}$ averaged over the whole basin. The error limits allow that the budget may be close to zero but definitely not negative. A similar result is implied from the budget of the total drainage basin, with an average rise rate of $0.04 \mathrm{~m} \mathrm{a}^{-1}$. Earlier estimates of the mass budget of the Lambert Glacier basin (Mellor, 1959[a]; Budd and others, 1967; Giovinetto, [1970]) also gave mass surpluses of comparable or greater magnitude. Budd and others ([ [ 970$]$ ) also imply a positive budget from the fact that the calculated balance velocity for the Amery Ice Shelf is about twice the measured velocity.

Table V. Mass budget of the Lambert Glacier drainage basin

\begin{tabular}{|c|c|c|c|c|}
\hline & & $\begin{array}{c}\text { Interior } \\
\text { basin }\end{array}$ & $\begin{array}{l}\text { Lambert Glacier } \\
\text { system }\end{array}$ & $\begin{array}{l}\text { Total drainage } \\
\text { basin }\end{array}$ \\
\hline Inflow & $\left(\mathrm{Gt} \mathrm{a}^{-1}\right)$ & - & +30 & - \\
\hline Gain within basin & $\left(\mathrm{Gt} \mathrm{a}^{-\mathrm{I}}\right)$ & +60 & -7 & $\begin{array}{r}+60 \\
-7\end{array}$ \\
\hline Outflow & $\left(\mathrm{Gt} \mathrm{a}^{-1}\right)$ & -30 & -11 & $-I I$ \\
\hline Budget & $\left(\mathrm{Gt} \mathrm{a}^{-1}\right)$ & +30 & +12 & +42 \\
\hline Estimated limits of budget & $\left(\mathrm{Gt} \mathrm{a}^{-\mathrm{I}}\right)$ & $(+3$ to +79$)$ & $(-4.5$ to +28$)$ & $(+9$ to +89$)$ \\
\hline Area & $\left(\mathrm{km}^{2} \times 10^{3}\right)$ & I ogo & 62 & I 152 \\
\hline \multicolumn{2}{|c|}{ Mean annual surface-level change ( $m$ water $a^{-1}$ ) } & +0.03 & +0.19 & +0.04 \\
\hline \multicolumn{2}{|c|}{$\begin{array}{l}\text { Estimated limits of surface-level change } \\
\qquad\left(\mathrm{m} \text { water } \mathrm{a}^{-1}\right)\end{array}$} & +0.003 to +0.07 & -0.07 to +0.45 & +0.01 to +0.08 \\
\hline
\end{tabular}


Similar positive budgets have also been found for other Antarctic drainage basins: the western part of the Ross Ice Shelf (Giovinetto and others, I966); the eastern part of the Ross Ice Shelf (Giovinetto and Zumberge, I 968) (although Whillans (1977) obtains a negative balance for this basin from a study of velocities along the flow line through Byrd Station), and for the section of Antarctica which drains through the coast of Terre Adélie (Lorius, 1962). The fact that most studies of the mass budget of Antarctic drainage basins up-stream of the grounding line give a positive result tends to indicate the general validity of the many earlier, admittedly crude, but almost always positive, mass-budget estimates of the whole of Antarctica (e.g. Loewe, 1967; Bardin and Suyetova, 1967).

Within the Lambert Glacier system the results of Table $\mathrm{V}$ indicate a fairly rapid surface rise of $0.19 \mathrm{ma}^{-1}$, although error limits do permit the budget to be marginally negative. While loss by melt water within the basin was not considered, it is difficult to see how any such loss could account for the total imbalance, and the overall indication is that the ice level is rising.

Geomorphological evidence indicates that the ice levels in the Lambert Glacier system have fallen drastically at some time in the past. Glacial striae, roches moutonnées, and moraine deposits are widespread on summits up to $800 \mathrm{~m}$ above the present ice (Tingey, 1974) and the crests of lateral moraines alongside the smaller valley glaciers of the Mawson escarpment are $50 \mathrm{~m}$ above the present glacier surface (Mellor, 1959[b]). Tingey (1974) claims that the preservation of striae in soft rocks and the retention of clay fractions in pockets of moraine indicate recent recession of the ice, while Mellor (1959[b]), on the basis of evidence from a water-cut gorge between Radok and Beaver Lakes, postulates that the ice of the Lambert Glacier region has not been much above its present level during the past few hundred years. If then, the ice level in the Lambert Glacier basin is currently rising, as strongly suggested by the mass budget, it can only have been doing so for a comparatively short time.

Hollin (1962, [1970]) fails to find any evidence for major fluctuations at the Antarctic Ice Sheet margins and suggests that a positive mass budget would imply a surge-type build up in the interior of the ice sheet. Budd and McInnes ( $\left[{ }^{c}{ }_{1978}\right)$ ) have applied a surge model to the east Antarctic flow line through Mirny and suggest that the Lambert Glacier system also has a high potential for surging. Their preliminary modelling results suggest rapid collapse of the coastal regions of the ice sheet during a surge, with much less surface lowering further inland. After the surge the ice sheet builds up slowly to its pre-surge maximum elevation. While not confirming the existence of surges, neither the geomorphological evidence nor the mass balance results for the Lambert Glacier basin preclude the possibility of their occurrence. If surges do occur the balance results imply that the basin could be undergoing a post-surge build-up, and that it will take about five thousand years at the present rate before reaching the previous elevation $800 \mathrm{~m}$ above the present level. During this period the interior basin would rise by about $100-200 \mathrm{~m}$, which is in general agreement with the modelling results.

\section{Acknowledgements}

The assistance of all members of the A.N.A.R.E. 1971/72 and 1973/74 Prince Charles Mountains parties, and particularly the leader of the survey teams, J. Manning, and my colleagues on the ice, M. Skinner (197/ / 72) and C. Austin (1973/74), is gratefully acknowledged. Special thanks are due to W. F. Budd for providing the Amery Ice Shelf data and for many valuable discussions.

MS. received 26.7 uly 1.978 and in revised form .9 October 1.978 


\section{REFERENC:ES}

Bardin, V. I., and Suyetova, I. A. 1967. Basic morphometric characteristics for Antarctica and budget of the Antarctic ice cover. (In Nagata, T., ed. Proceedings of the symposium on Pacific-Antarctic sciences. Tokyo, Dept. of Polar Research, National Science Museum, p. 92 - oo. (Japanese Antarctic Research Expedition. Scientific Reports, Special Issue No. 1.))

Budd, W. F. I 966 . The dynamics of the Amery Ice Shelf. Journal of Glaciolog), Vol. 6, No. 45, p. 335-58.

Budd, W. F. 1967. Ablation from an Antarctic ice surface. (In Oura, H., ed. Physics of snow and ice: international conference on low temperature science. . . 1966. . . Proceedings, Vol. 1, Pt. I. [Sapporo]. Institute of $\mathrm{Low}$ Temperature Science, Hokkaido University, p. $431-46$.)

Budd, W. F., and McInnes, B. ['1 1978 .] Modelling surging glaciers and periodic surging of the Antarctic ice sheet. In: Pittock. A. B., and others, ed. Climatic change and variability: a southern perspective. Editors: A. B. Pittock, L. A. Frakes, D. Jenssen, 7. A. Peterson, 7. W. Zillman. Cambridge, etc., Cambridge University Press, p. 228 33.)

Budd, W. F., and others. 1967. The Amery Ice Shelf, by W. [F.] Budd, I. [H.] Landon-Smith, and E. [R.] Wishart. 'In Ōura, H., ed. Physics of snow and ice: international conference on low temperature science. . . 19fif. ... Proceedings, Vol. 1, Pt. 1. [Sapporo], Institute of Low Temperature Science, Hokkaido University. p. $447-67$.)

Budd, W. F., and others. [1970.] The extent of basal melting in Antarctica, by W. [F.] Budd, D. Jenssen, and U. Radok. Polarforschung, Bd. 6, Jahrg. 39, Nr. 1, 1969 , p. 293-306.

Bull, C. B. B. 1971 . Snow accumulation in Antarctica. (In Quam, L. O., ed. Research in the Antarctic. A symposium presented at the Dallas meeting of the American Association for the Adrancement of Science-December 1968 . Washington. D.C.. American Association for the Advancement of Science, p. 367-421.)

Fedorov, L. V., and others. In press. Crustal structure of the Lambert Glacier area from geophysical data, by I. V. Fedorov, G. E. Grikurov, R. G. Kurinin, and V. N. Masolov. (In Craddock, C., ed. Antarctic geoscience. Proceedings of the third Symposium on Antarctic Geology and Geophysics, Madison, 22-27 August, 1.977. Madison. University of Wisconsin Press.)

Fujiwara, K., and others. 1971. Survey and some considerations on the Antarctic ice sheet, [by] K. Fujiwara, S. Kakinuma, and Y. Yoshida. (In Murayama, M., ed. Report of the Fapanese tracerse Syowa South Pole 1968-196ig. Tokyo, Polar Research Center, National Science Museum, p. 30-48. (Japanese Antarctic Research Expedition. Scientific Reports, Special Issue No. 2.))

Giovinetto, M. B. Ig64. The drainage systems of Antarctica: accumulation. (In Mellor, M., ed. Antarctic snow and ice studies. Washington, D.C., American Geophysical Union, p. 127-55. (Antarctic Research Series, Vol. 2.))

Giovinetto, M. B. [1970.] The Antarctic ice sheet and its probable bi-modal response to climate. [Union Géodésique et Géophysique Internationale. Association Internationale d'Hydrologie Scientifique.] [International Council of Scientific Unions. Scientific Committee on Antarctic Research. International Association of Scientific Hydrology. Commission of Snow and Ice.] International Symposium on Antarctic Glaciological Exploration (ISAGE), Hanozer, Vew Hampshire, U.S.A., 3-7 September 1.986, p. 347-58. [(Publication No. 86 [de l'Association Internationale d'Hydrologie Scientifique].)]

Giovinetto, M. B., and Zumberge, J. H. 1968. The ice regime of the eastern part of the Ross Ice Shelf drainage systcm. Union de Géodésie et Géophysique Internationale. Association Internationale d'Hydrologie Scientifique. Assemblée générale de Berne, 2.5 sept.-7 oct. 1967. [Commission de Veiges et Glaces.] Rapports et discussions, p. 255-66. (Publication No. 79 de l'Association Internationale d'Hydrologie Scientifique.)

Giovinctto, M. B., and others. 1966. The regime of the western part of the Ross Ice Shelf drainage system, by M. |B.] Giovinetto, E. S. Robinson, and C. W. M. Swithinbank. Journal of Glaciology, Vol. 6, No. 43, p. 55-68. Hollin, J. T. 1962. Some problems of the Antarctic mass budget. Fournal of Glaciology, Vol. 4, No. 33, p. 312-14.

Hollin, J. T. [1970.] Is the Antarctic ice sheet growing thicker? [Union Géodésique et Géophysique Internationale. Association Internationale d'Hydrologie Scientifique.] [International Council of Scientific Unions. Scientific Committee on Antarctic Research. International Association of Scientific Hydrology. Commission of Snow and Ice.] International Symposium on Antarctic Glaciological Exploration (ISAGE), Hanover, New Hampshire, U.S.A., 3-7 September 1968, p. 363-74. [(Publication No. 86 [de l'Association Internationale d'Hydrologie Scientifique].)]

Kotlyakov, V. M., and others. 1974. Novaya karta pitaniya lednikovogo pokrova Antarktidy [New map of the accumulation on the Antarctic ice sheet]. [By] V. M. Kotlyakov, N. I. Barkov, I. A. Loseva, V. N. Petrov. Materialy Glyatsiologicheskikh Issledovaniy. Khronika. Obsuzhdeniva, Vyp. 24, p. 248-55.

Loewe, F. 1967 . The water budget in Antarctica. (In Nagata, T., ed. Proceedings of the symposium on PacificAntarctic sciences. Tokyo, Dept. of Polar Research, National Science Museum, p. 101-10. (Japanese Antarctic Research Expedition. Scientific Reports, Special Issue No. 1.))

Lorius, C. 1962 . Contribution to the knowledge of the Antarctic ice sheet : a synthesis of glaciological measurements in Terre Adélie. Journal of Glaciology, Vol. 4, No. 31, p. 79-92.

Mellor, M. 1959[a]. Mass balance studies in Antarctica. Fournal of Glaciology, Vol. 3, No. 26, p. $522-33$.

Mellor, M. 1959[b]. Variations of the ice margins in East Antarctica. Geographical Journal, Vol. 125, Pt. 2,

p. ${ }^{230-35 .}$
Mellor, M. ${ }^{1964}$. Remarks concerning the Antarctic mass balance. Polarforschung, Bd. 5, Jahrg. 33, Ht. I-2, 1963 , p. $179-80$.

Mellor, M., and McKinnon, G. W. 1960. The Amery Ice Shelf and its hinterland. Polar Record, Vol. 10, No. 64,

p. 30-34.
Morgan, V. I., and Budd, W. F. 1975. Radio-echo sounding of the Lambert Glacier basin. Fournal of Glaciology, Vol. ${ }_{15}$, No. 73 , p. $103-11$ 
Shimizu, H. 1977. Corrected result of altimetric surveys of ice sheet surface made in 1969-1975. (In Watanabe, O., ed. Cilaciological research program in Mizuho Plateau west Enderbv Land, East Antarctica. Pt. 4. 1974 1975. Tokyo, National Institute of Polar Research, p. 170-82. (Japanese Antarctic Research Expedition. JAR I Data Reports, No. 36 (Glaciology).))

Tingey, R. J. 1974. Australian geological mapping in the Prince Charles Mountains, 1968-73. Polar Record. Vol. 17, No. 107, p. $150-53$.

Tingey, R. J. In press. The geology and geological evolution of the Prince Charles Mountains, Antarctica. (In Craddock. C., ed. Antarctic geoscience. Proceedings of the third Symposium on Antarctic Geology and Geophysics, Madison, 22-27 August, 1977. Madison, University of Wisconsin Press.)

Trail, D. S. ${ }^{1964}$. The glacial geology of the Prince Charles Mountains. (In Adie, R. J., ed. Antarctic geolog). Proceedings of the first international symposium on Antarctic geology, Cape Town, 16-21 September 1963. Amsterdam. North-Holland Publishing Co., p. 143-51.)

Weertman, J. 1973. Can a water-filled crevasse reach the bottom surface of a glacier? Union Géodésique et Géophysique Internationale. Association Internationale d'Hydrologie Scientifique. Commission de Neiges et Gilaces. Symposium on the Hydrology of Glaciers, Cambridge, 7-13 September 1969, p.139-45. (Publication No. 95 de l'Association Internationale d'Hydrologie Scientifique.)

Wellman, P., and Tingey, R. J. 1976. Gravity evidence for a major crustal fracture in eastern Antarctica. BMR Journal of Australian Geology and Geophysics (Bureau of Mineral Resources, Geology and Geophysics), Vol. 1, No. 2, p. $105^{-08}$.

Whillans, I. M. 1977. The equation of continuity and its application to the ice sheet near "Byrd" Station, Antarctica. Journal of Glaciolog), Vol. 18, No. 80, p. 359-71. 